\title{
Computation of the Seismic Stability of Earth Retaining Structures
}

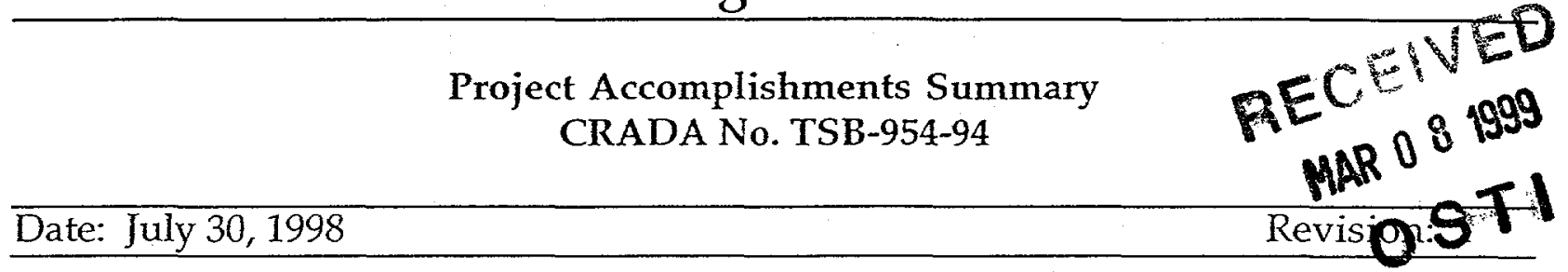

A. Parties

The project was a relationship between the Lawrence Livermore National Laboratory (LLNL) and StablEarth Systems.

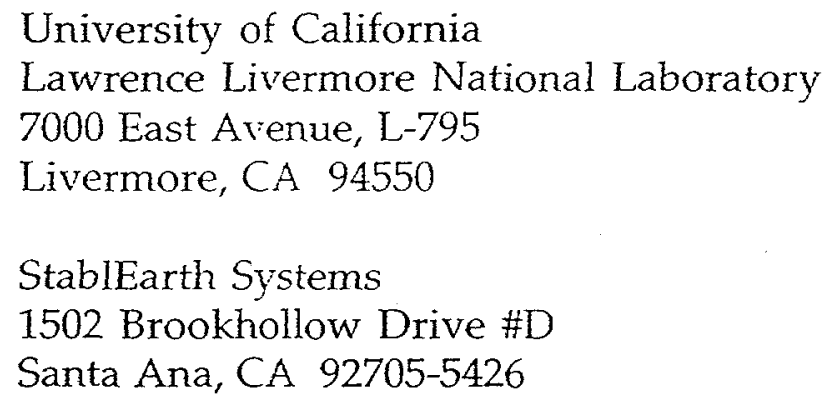

\section{B. Background}

Major earthquakes in the State of California (Loma Prieta 1989, Cape Mendocino 1992, Landers 1993 and Northridge 1994) underscored the economic and life-safety threat to the State of California and other seismically active regions of the United States. The Northridge earthquake was not exceedingly large (Richter magnitude of 6.4), however the economic implications were immense. The most recent damage estimates for the Northridge earthquake, compiled by the California Office of Emergency Services, put the total damage costs at $\$ 15-20$ billion with insured damage losses of $\$ 4$ billion. The Insurance Research Council estimated that if a 7.5magnitude quake hit the Los Angeles area, total insured losses would reach $\$ 50$ billion (over ten times that of the Northridge quake) - which is more covered damage than all natural disasters caused between 1972 and 1991. The awareness brought on by the earthquakes in 1989,1992, 1993 and 1994 in California translated into an urgent desire by governmental officials to become proactive in solving important seismic hazard issues.

In light of the catastrophic life-safety and economic consequences of a major earthquake, LLNL brought together, in a formalized way, LLNL resources to be used to address earthquake hazard problems. 


\section{DISCLAIMER}

This report was prepared as an account of work sponsored by an agency of the United States Government. Neither the United States Government nor any agency thereof, nor any of their employees, make any warranty, express or implied, or assumes any legal liability or responsibility for the accuracy, completeness, or usefulness of any information, apparatus, product, or process disclosed, or represents that its use would not infringe privately owned rights. Reference herein to any specific commercial product, process, or service by trade name, trademark, manufacturer, or otherwise does not necessarily constitute or imply its endorsement, recommendation, or favoring by the United States Government or any agency thereof. The views and opinions of authors expressed herein do not necessarily state or reflect those of the United States Government or any agency thereof. 


\section{DISCLAIMER}

Portions of this document may be illegible in electronic image products. Images are produced from the best available original document. 
The focal point for this effort was the newly formed Geologic and Atmospheric Hazards Project in the Geosciences and Environmental Research Program. The Geologic and Atmospheric Hazards Project coordinated existing LLNL core capabilities in engineering and the physical sciences, and drew on technology developments from Laboratory Directed Research and Development Projects (LDRD) projects, to provide various customers at the state and federal level (e.g. Caltrans, Department of Energy, University of California, California Division of the State Architect) a full capability in seismic hazard mitigation.

Engineering staff of StablEarth had experience in the design and construction of reinforced earth systems and block walls. StablEarth provided all data block wall properties and earth reinforcing properties. StablEarth also performed a design of a typical wall/soil system to be used in the computer simulation. StablEarth also obtained data from experimental, industry sponsored, testing to ascertain the pull-out capacities of earth reinforcing material.

\section{B. Description}

The purpose of this CRADA project was to evaluate the seismic stability of block retaining wall systems. Retaining wall systems are used extensively in private and commercial developments.

This study was designed to develop and demonstrate a computer modeling technology to be used to predict the seismic stability of any block wall system design. The nonlinear finite element computer programs developed at LLNL and employed in the Computational Earthquake Initiative were utilized in this small business CRADA to analyze the seismic stability of the block retaining walls. The unique capability of the LLNL programs to rigorously model frictional contact in a dynamic analysis problem were used in a computer simulation of the dynamic interaction the block wall/soil systems under seismic excitation.

Another important application, and the focus of the proposal, was the use of block retaining walls in highway transportation systems to provide a vertical wall to hold back a mass of soil near highway bridges, and at on-ramps and off-ramps. Block retaining walls offered the potential of highway retaining wall construction which was both more flexible and more economical than existing poured-in-place and tilt-up highway retaining wall construction. However, block retaining wall technology was not embraced and utilized in the State of California as a result of seismic stability concerns expressed by Caltrans. Caltrans had an interest in utilizing block wall systems as soil retaining systems for major highway structures in California, but they stated to the block wall manufacturers and the manufacturer's engineering consultants that block retaining walls could not be employed until Caltrans was convinced of the earthquake stability of such systems. 


\section{Economic Impact}

Seismic concerns became an impediment to the implementation and sale of block retaining walls in the State of California. It should also be noted that public transportation organizations and local governments throughout the entire country looked to California as the leader in establishing seismic criteria for transportation systems. Seismic acceptability of the block retaining wall systems in California set a precedent for acceptance across the nation.

\section{Benefits to Block Wall Industry}

The ability to rigorously predict wall stability under seismic excitation has the potential of significantly expanding the market for block wall manufacturers. The focus of this work was transportation structures, however, these walls could also be utilized in many other applications and determination of seismic stability would also benefit other applications of block retaining wall technology. The U.S. manufacturers included (all are considered small businesses and all benefited from the proposed work): Versa-Lok, StoneWall, GravityStone, Greystone, Cornerstone and Keystone. Keystone was the leading manufacturers with the most widespread applications. StablEarth estimated that Caltrans approval of the block wall technology would open new markets with estimated capitalization in excess of $\$ 50$ million.

\section{Benefits to StablEarth}

As engineering and geology consultants to a number of retaining wall and reinforced earth companies, development of a procedure for analysis of block wall systems provided StablEarth with a tool for demonstrating the stability of block wall systems industry wide. There was also an element of technology transfer in that StablEarth was in the process of developing an in-house computer analysis capability for wall systems, and they utilized LLNL software tools in this effort.

\section{Benefits to LLNL}

This project provided an opportunity for LLNL to apply the finite element computer software developed at LLNL on a difficult, important problem which has yet to be solved by anyone else. The dynamic interaction of discrete blocks was a very difficult analysis problem and LLNL programs had unique capabilities which were showcased by solution of this difficult problem.

This CRADA provided an opportunity for contribution by LLNL in the civil engineering/infrastructure area in which the newly formed Geologic and Atmospheric Hazards Project (Dr. Bob Murray) and the EMATT Transportation Program (Dr. Frank Tokarz) were actively involved in marketing of LLNL capabilities and thus contributed to new dimensions of the LLNL mission. 
The analysis approach defined in this problem application had a number of spin-off applications, including the seismic analysis of bridge abutments and soil systems, the analysis of underground structures (e.g. bunkers under blast and earthquake loads) where interaction between the soil and structure were modeled.

\section{Benefits to the State of California}

This problem also had a significant element of public service in that it helped provide the State of California with a rational means of assessing the safety and stability of important transportation structures. Caltrans had a high level of interest in utilizing the stacked block walls in their earth retaining structures. Demonstrating seismic stability allowed them to employ these wall systems in the state of California. Specific benefit to the state included a neiv cost-competitive solution to retaining wall construction.

\section{Benefits to DOE}

This project was consistent with the DOE's mission of Technology Transfer and provided benefits and positive impact on both DOE and the partners. This program did not negatively impact any current DOE program.

Demonstration and validation of the capability of seismic response computations for gravity block wall also led to applications of this technology in the DOE complex. The seismic stability of stacked concrete shielding blocks came into question at a number of DOE sites, and development of rigorous solution techniques for gravity blocks had direct application to this problem. Assessing the seismic stability of retaining wall structures and unreinforced masonry structures at DOE sites also benefited from this study. Through the Geologic and Atmospheric Hazards Project, LLNL was a principal contributor to seismic criteria development and seismic evaluation for the entire DOE complex.

E. Industry Area

Construction (residential, commercial and highway)

\section{F. Project Status}

This project was completed December 8, 1995.

H. LLNL Point of Contact for Project Information

LLNL was represented by David B. McCallen (Principal Investigator, L-196, 925/423-1219 and 925/424-5489 (fax) from the ME/Structural Mechanics Group 
I. Company Size and Point(s) of Contact

StablEarth Systems was represented by Principal Investigator, Steve Miller, President, 714/708-7145; 714/708-7418 (fax). Company sales are approximately $\$ 2.5$ million, and the company employs $<5$ people.

\section{J. Project Examples}

A final report was provided by LLNL.

\section{K. Subject Inventions}

This small value contractual mechanism did not anticipate any generation of Intellectual Property (IP) including subject inventions. To the best of our knowledge no IP was created.

$\square$ Yes $X$ No

$$
\text { If yes, list all IP created under this agreement }
$$

\section{Release of Information}

I certify that all information contained in this report is accurate and releasable to the best of my knowledge.
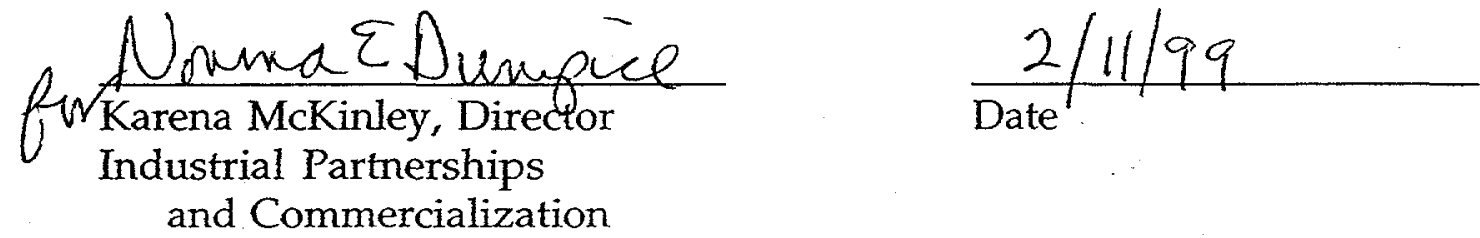

\section{Release of Information}

I have reviewed the attached Project Accomplishment Summary prepared by Lawrence Livermore National Laboratory and agree that the information about our CRADA may be released for external distribution.
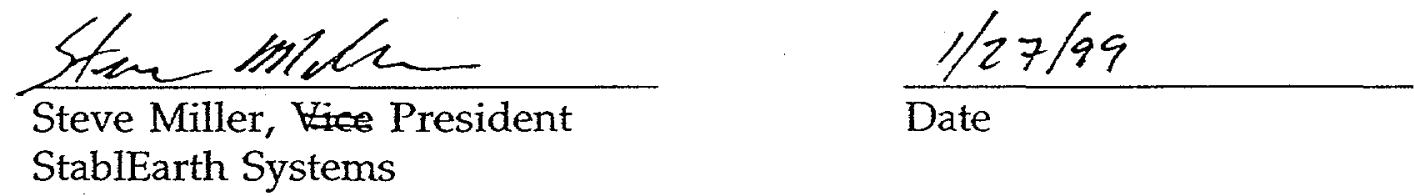

StablEarth Systems 